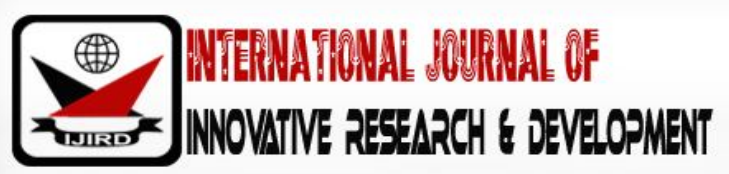

ISSN 2278 - 0211 (Online)

\section{African Trade and World Trade Organization Market Share: A Case for the Establishment of African Economic Trade Organisation (AET0)}

\author{
Idibia Daniel Obida \\ Legal Practitioner \& Ph.D. Student, Jurisprudence \& International Law Department, \\ Faculty of Law, University of Lagos, Nigeria
}

\begin{abstract}
:
This study sets out to investigate the factors that determine regional trade networks within Africa and argues for the need to for a legal framework for promoting Africa, development strategies were modeled after foreign standards and have largely failed because they were initiatives of and patterned after Western interest and elements. The development plans were in form of aid from Overseas Development Association, (ODA), and bilateral trade including soft loans from World Bank. The study argues that building on those foreign ideas without taking into consideration the economic culture of Africa, which is the foundation for sustainable development are false steps which have never and will never liberate Africans from dependency. The study suggests change in sub-regional sectors of Africa are regrouping for better opportunities by way of economic gains and promotion of democracy. The study posits that the best way to secure foundation for Africa's growth is to have her own trade organization that will carter for the needs of African trade because the end purpose of African Economic Trade Organization (AETO). African states need to pool her resources together under one single organization for global competitiveness and balance of payments. The proposed AETO framework advocates a made- in- Africa-for African market Organization. The study concludes that the formation of this organization will incorporate indigenous knowledge where Africa will have a decisive voice in formulating her policies on resource that the current market shares at WTO African trade development.
\end{abstract}

Keywords: GATT/ WTO, foreign aid, LDCs, economic development, law \& economic.

\section{Introduction}

Law and development are fused in modern economic planning especially from the angle of economic rights, whichconstitute a question of law that addresses issues, solve problems of unequal bargaining power and also play significant role where power-basedissues are employed in negotiations as opposed to a law-based platform. The idea of how law is being used for economic and trade development purposes as contained in GATT rules as annexed to World Trade Organization is lacking in Africa; at least in a single document. This is one of the core problems and the difficulties in evaluating the growth of trade on the continent. This study proposes an urgent need for a home-grown legal framework of development on for a single trade organization that is made in Africa for Africa. The continent has nothing to show in terms of her trade growth since her participation at WTO for the past one decade. Foreign development assistance in form of Official Development Assistance (ODA) which could have developed African countries' economy have failed due to none incorporation of homegrown ideologies of the natives' priority on the region. In Africa, any development plan meant to aid Africa must necessarily take into account their priorities and start development from there. This has not been the case in aid era because most of the foreign ideas of development have been forced on the recipients of aid which portrays case of feeding Africa with purgative opium. This study reiterates the need for Africa to start thinking on the idea of a legal framework for the establishment of her own Economic Trade Organization (AETO).

Developments in Africa have taken more talk than action in the last two decades. Ideas proposed on how to develop Africa is akin to doing God's work by accident rather than by design and these have, thus far, failed to promote development in terms of institution, human and economic growth in the region. Given the foregoing, Easterly noted that 'the ideology of African development should be packed up in crates and sent off to the Museum of dead ideologies. The importance of the above statement is that most of the suggested ideologies of development in Africa came from foreigners and they failed Africa one way or the other as the ideas did not incorporate the needs and priorities of the area of development needs of the people 
they sought to develop. Development shares common ideologies with both the developed and developing nations. One of the key questions for the promotion of economic development is how effective has the membership of African countries at WTO aided her trade promotion. This position is arrived at because of the failure of GATT rules to make any major impact on the growth of the regions' trade at the World Trade Organization. The woeful result of trade stagnation has made it very necessary for Africa to search within her region for her own trade organization that will promote growth of trade of member countries. Besides, Africa has little share of the global market. For instance, there is a continuous tariff on agriculture, cotton and textiles goods import from Africa by most countries in Europe and America through the exceptions to quantitative resections. ${ }^{1}$

Legal thoughts had it that true revolutions of development are centered on legal architecture to promote and solve problems of development of commercial agreements; this makes mandatory for Africahave a sound legal document for her trade institution. The failure of development of some African regions has been due to the imposition of external agreements which do not suit the terrain of Africa's development economy. The ideas are clog with rigidity of rules and dictates of the West on the world's poor, thus accounting for the miserable failures of development that have been witnessed in the continent. Every society needs development whether in law or economic. The Least Developed Countries (LDCs) needs development to compete favorably in foreign earnings and balance of payments through international trade in order to raise the standard of living the people in the continent. ${ }^{2}$ The developed countries also need development in terms of new ideas, technologies and political maneuvering over their competing counterpart in production of goods and service in areas of trade domineering and raw materials which most sources are obtained from developing countries of Africa, Asia and the pacific.Initially, when the idea of free market was introduced by Europe and America, it was received with warm hearts by Less Developed Countries but when most products such as Cotton and Agriculture from Africa were fettered with clauses in the various agreements with stiff tariffs and quantitative restrictions, it made a caricature of WTO's supposed 'good intention.

\section{Trade Liberalization and Africa'sQuest for EconomicDevelopment.}

Trade liberation came from the West and Europe and embraced by developing countries. Ordinarily, there is nothing wrong with the idea of free trade or trade liberalization. The conception of free trade idea was intended to enhance the markets of the produces from the continent of Africa. However; the argument is that it was presented inan unworkable way that would never lead to economic development through trade in Africa. One of the reasons why Africa will struggle in vain in WTO is that free market as presented by WTO, is with unelected outsiders imposing certain rigid principles of trade and tariffs on the unwilling people of developing countries who have limited choice in the matter because of power play of the developed countries with less economic bargaining power in Africa. The share of the market allocated to Africa by Europe and America or developed countries as they are popularly referred to at the WTO level is too small. Africa does not have the force needed in technology in manufacturing capabilities to compete with the developed countries and hence, the competing priority for Africa should be to grow at her own pace on a regional basis for her trade stability and development. It is axiomatic that some countries in Africa believes that free manna would emanate from WTO to fast-track its trade opportunities. This is will never happened as long as GATT rules is the major legal document being used by WTO. The history of laws of Most Favoured Nation (MFN) principle and National Treatment - non-discrimination over the years have proved the fertility a misadventure of the application of GATT rules in Africa's trade participation.

Africa must take deliberate steps to expound her trade interventions in economic trade and if there is any time to do this, it's now. Seeking redress for certain treatments of Africa's participation at WTO, such as inequality, political power show on agreements on Textile/ Cotton and agriculture; which tariffs have remained unchanged after several years of negotiation between the developed and developing countries, the only way forward for African countries is to have an African trade organization. Some sort of supper regional arrangement that would coordinate the affairs of her trade at the global level. It has not been established both in practical terms and on paper that any of the 28 members of Africa countries who are members of WTO have indeed benefited from the trade bargain. Whalley ${ }^{3}$ argues that one of benefits which most developing countries relies upon was the 'special rights to protect and preferential market access. This was characterized by wide range of delays with clumsy exemptions from developed countries in the name of technical assistance and some other provisions.

This study argues there is an evidence of short-changing developing countries of Africa in terms of the rules of GATT which is sacrosanct. It is therefore arguable that Africa would be far off better without its membership in WTO. Arguing this point further, the 1947 rules of GATT as they stand today are not beneficial to African trade development because when that

\footnotetext{
${ }^{1}$ Article XX II \& XXIII*B) of GATT.

${ }^{2}$ F. G. Snyder, "Law and Development in the Light of Dependency Theory" (1980) Law \& Society Review, Vol. 14, No. 3, Contemporary Issues in Law and Social, pp. 723-804.Published by Wiley for Law and Society Association. This paper argued that modernisation adopted a notion of social change that emphasizeddifferentiation and integration. It further stated that it postulated a conception of modernity that was formal and a historicalbut teleological. Africa economic development has defied most theories of development.

${ }^{3}$ Whalley, J., "Special and Differential Treatment in the Millennium Round" (1999) Centre for the Study of Globalisation and Regionalisation (CSGR), University of Warwick, Coventry CV4 7AL, United-Kingdom. Available online at www.csgr.org.Accessed on the 15/11/ 2016.

"The "DOHA" deadlock is a chronic example of how developed countries are unwilling to shift grounds to pave way for Africa and India to expand their trade. Furthermore, rather than apply rule-based to negotiation, Power-based against Rule-based negotiation are applied most of the time.
} 
rule was being made, most countries in African regions were shared amongst the colonial masters. This means that their interest was subsumed into to their colonial masters as it is not on record that there any representative in the forum of GATT during that period. The study suggest that Africa should review the sufficiency or otherwise of the existing commercial trade laws between African and advanced countries. The study sets out to propose a legal framework for the establishment of an African Economic Trade organization (AETO) which will serve as a parallel trade organization to counter the treatments received at WTO in terms of unequal trade bargain and tariff negotiation on common similarities of produce from region.The rules of GATT as annexed to WTO had finally reduced the continent to perpetual dependency. Africa has also failed her people by her continuous membership of the organization without an attendant contributory success of the continent's trade growth. Thewriter suggests the need for Africa to establish its own system of trade of international nature within the continent. The trade organization would tackle the trade affairs of Africa like the World Trade Organization did for Europe.5WTO has sought legitimacy for itself and for the underlying institution of free trade.

There are some questions regarding its organizational mandate and management of international trade negotiations. It is argued that Africa can equally sort for its trade institutions and decide on how it wants to deal with its trade adventure at WTO. The issue of equal representation at WTO had been canvassed by many African countries but they were all treated with levity. Furthermore, WTO is fraught with competing model of unrealistic dreams of free trade. Daemmrich found that the WTO dispute settlement process is helping to legitimize the institution of free trade through its public display of rational authority. ${ }^{6}$ However, on the other hand, dispute panels have passes judgment most of the time on issues of econometrics and scientific uncertainty.7 This practice have brought doubts for the broader legitimacy of the WTO as it has shifted from questions of representation that have long drawn attention to epistemic issues which typically manifest in controversies over specific claims between member countries. Additionally, as argued byStepek, there are always political interests vested in the status quo of any legal system, and overcoming those interests to pursue root and branch reform is extremely difficult.8Tellingly, globalization has made things simpler rather than complex but human beings managing the affairs of trade globalization have made it more difficult for the less developed countries. The place of Africa's future trade in WTO remains in limbo as the rule of GATT is rather on power-based rather than rule-based. 9 Furthermore, the international regulation of GATT rules is important in the promotion of trade but this study argues that its scale tilts to the side of its founding fathers who from inception, basically understood the rules and wield political powers to deliberate and shift grounds on political reason rather than rule-basedplatform. It is therefore increasingly becoming more important that there are technical areas which developing countries of Africa need backup.

The unfair treatment at WTO of Africa is noticeable. It was what led to the negotiation on the issues of "Special and "Differential Treatment" but even that has now become a lullaby of auditory hallucination. Africa needs a unified vehicle to ventilate her grievances at the world trade level. This is because one of the most common knowledge shared by mankind is commercial agreements on sales of goods and services between individuals and nations. Trade commonly unites people globally and also disunites nations globally depending on pursued interests and often times where a question of interest is involved; it may lead to an unending economic war between countries.The Most Favoured Nations rule of GATT has not favoured any country in Africa in terms of manufactured goods. Likewise, the Special Differential Treatment (S\&D) pursuit has also failed Africa. ${ }^{10}$ The fundamental idea that 'no cap fits all' was the reason behind the S\&D. In GATT rule, S\&D was codified as normative in 1979 in what is referred today as "enabling clause." Basically, it was supposed to provide for preferential treatment for developing countries on a non-reciprocity basis. Historically, trade context which emerges from the call for differentiation concerning exemptions and some form of assistance afforded to developing countries were meant to uplift the enlargement of the market share of Africa. This never happened as most negotiations which were supposed to promote the S\&D treatment ended up in a deadlock because different economic interest and lack of accommodation of African interest by Europe and America.The effect of the above rule further shattered the hope of trade promotion and development in Africa which ought to commensurate the needs of Africa and other developing countries. The S\&D rules sets out at the initial stage as

\footnotetext{
${ }^{5}$ Daemmrich, A., "Epistemic Contests and Legitimacy of the World Trade Organization: The Brazil — USA Cotton Dispute and Incremental Balancing of Global Interests" (2012) 200, Vol. 4(1) Trade, Law \& Development

${ }^{6}$ Ibid.

${ }^{7}$ Contra Boris Kozolchyk, who argues that Commercial legal institutions that are being used uniformly throughout the trading world earn their universality by incorporating best commercial practices. These are the practices that have proven their cost-effectiveness and fairness regardless of the marketplace in which they were first used.

${ }^{8}$. Stepek, M. J., "The Importance Of Commercial Law In The Legal Architecture Of Post-Conflict "New" States" (2008) 60 Me. L. Rev. 487, For further reading on what diversity of laws does to people of divergent race, see Stephen Macedo, "The Law of Peoples What Self-Governing Peoples Owe to One Another:

Universalism, Diversity, and the Law of Peoples" (2003-2004), 72 Fordham L. Rev. 1721/. Available online at HeineOnline.Accessed on 12/1/2017. ${ }^{9}$ The argument is that certain project designed to create an enforceable commercial law may not necessarily be welcomed by the political leaders in any given state especially those with economic powers. Also, more importantly, there are always political interests vested in the status quo of any legal system, and overcoming those interests to pursue root and branch reform is extremely difficult. Any legal reform requires compliance by a client country's political leaders which in the case of GATT, its founders find favors in power-based politics rather than rule based.

${ }^{10}$ Hoeckman, B.,(2005) Vol. 8(2), 405-424Operational sing the Concept of Policy Space in the WTO: Beyond Special and Differential Treatment. In Reforming the World Trading System (Reforming the World Trading System, Chapter 11). Journal of International Economic Law.
} 
demanded by some countries in Africa and India to give preferential treatment to Africa's trade in the area of Cotton and Agriculture. It later turned out to bitter pill to be swallowed by the continent as its interpretation turned out to be different from the expatiations by Africa and India because of the heavy tariffs attached to it as a bargain.

The reciprocity and transparency doctrine are all rules made in 1947 and even though globalization has moved beyond those years, it has become extremely difficult to change some of the rules of GATT to accommodate new development ideas of developing countries. The lack of shifting of grounds by developed countries only promoted so much of the imbalance of trade between the West and developing countries. Besides this, certain agricultural produce from Africa are laced with laws in America which prohibits them from entering American shores. ${ }^{11}$ The confirmation of the disagreement in the Uruguay Round records another weakling of WTO and the unwillingness of its founding fathers to reconsider the whole problem of economic growth of Africa through trade. For instance, exemptions in the rules promotes delays on implementation ${ }^{12}$ such that it is only a matter on paper for academic debates as it did not yield any benefit to Africa. It is argued that while prospects for global agreements may not be very feasible in its entirety in the light of the growth of scientific uncertainty, the option for Africa in the wake of failure of aid to promote its economy is an establishment of a single trade institution.

On the other hand, rules regulating trade ought to and should benefit the infant industries of Africa; the best option for Africa is to align itself to the formation of AETO to counter WTO which ideally, should be nicknamed "Euro-America International Trade Organization (EAITO).

It is now proper for Africa to have a regulatory framework for the establishment of a parallel trade organization within the region to serve as a vehicle where Africa may discuss its grievances of inequality treatment at WTO by the enforcement rule of 'Most Favoured Nation' (MFN) principle, the reciprocity doctrine, quantitative restrictions and unfair trade rules as they apply to the nations of Africa. The study further supports the current structure of other African regional organizations already in place, even though they are scattered; Africa can tap from some of the enabling legal frameworks in some of these sub-regional institutionsfor the establishment of AETO.

Developing countries cannot survive economically through trade as MFN rules are not rule-based but power-based which never favours developing countries. The rule treats unequal, equally and treats unequally, equal. For instance, Africa cannot be compared with the West and the rest of Europe in terms of development in the spate of technology. The moral heart of normative law and economics is efficiency, especially, dynamic efficiency that takes incentive effects into account. In the economic theory, justificatory argument is inherently at the institutional or rule-level, not the individual. ${ }^{13}$ Further to the above, it is now clear that the size of population of developing countries and the change in areas of need for development have increasingly become wider and can no longer be supported by the subservient treatment of the GATT as a role model. The option for Africa is trade, that is, Africa's own trade institution. Ideally, international trade with African produce ought to raise the income and the living standards of the people in the region if the advanced countries are willing to buy African produce through importation. Also, now that trading of African products at the global market has become very difficult, there is need to devise another means of economic growth within the region. GATT rules are too stringent for African countries to compete and prosperfrom trade with the developed countries at WTO. These accounts for the reason why this study is renewing the advocacy that rather than demanding for a fair deal for Africa at the GATT negotiating table, Africa need to have a legal framework for the formation of its own trade institution. ${ }^{14}$ Indeed, it has been argued that to release the potentials of Africa, the need to create a legal architecture as a means to facilitate trade across the African borders is non-negotiable. This study posits that while there are some successes in some regional arrangements, they are not all encompassing as the whole of African region need to speak with one voice at the global trade level in their trade bargains. This may include major investments in transport infrastructure including roads, ports, internal container depots, inland water ways and railways that are needed but lacking in some of the countries in Africa. ${ }^{15} \mathrm{~A}$ close view at the rules of GATT shows that the participation of Africa in WTO is just to mark register as the importance of creating export sectors to increase development through trade at WTO has lost its attraction. Thecontinued poverty on such a massive scale in Africa and other developing countries and its

\footnotetext{
${ }^{11}$ For instance, the Animal Rights Act. Certain African delicacies from bush meat which ordinarily earn foreign exchange abroad are not allowed to be exported into America as they are classified to be against Animal Rights.

${ }^{12}$ Hakan $\mathrm{H}$, et al note 5 , at page 3 .

${ }^{13}$ R. Hardin, “The Morality of Law and Economics” (1992) Vol. 11, No. 4, pp. 331-384 Law and Philosophy, Springer.Available at jstor.org.Accessed: 11/2/2017. Hardin's paper contends that the earlier Hart-Fuller debate concerned whether law is inherently moral. Whether there a minimal moral content to any legal system. Fuller thought the answer was obviously yes. For example, if law fails to serve the coordination function that he thought underlies all successful law, then it is likely to fail in application.

${ }^{14}$ Political dictators, social revolutionaries, technocrats, all these may make the laws by political fiat, with only the minimum possible participation by the lawyer in the making and execution of these laws. In societies that are based on the revolutionary upheaval of an established order and pursue radically new social and economic goals, the role of the lawyer tends to be depressed, his status lowly, his function limited.

${ }^{15}$ Barbara, R.,"Trade Not Aid: Why Trade Facilitation Is Important For Africa.” ( 2011), No. 27, Africa trade policy notes ; Washington, DC: World Bank. http://documents.worldbank.org/curated/en/676621468201835737/Why-trade-facilitation-is-important-for-Africa See also Jacobs, D., "Democratizing global economic governance', Paper presented at the Conference "Alternatives to Neoliberalism: New rules for global finance', (2000), NGO-Coalition, Monterrey. See also Yeoh, P., "international trade agreements and global economic governance" (2016) 37(8), 235-243, Comp Law
} 
stubborn resistance to the traditional solutions government expenditure, foreign aid, and private philanthropy indicates need for alternative ways to move masses of people up the income scale. ${ }^{16}$

It is on records that goods from Europe and the West attract high tariffs than those goods going from Africa to the West and Europe. Such areas include Textile, Cotton and Clothing which are of higher tariffs than other manufactured goods produced by developed countries. It is argued that if developing countries must pay high taxes (tariffs) and which would increase the price of products as it is eventually reflected in the market, it means that the economy of the developed countries would continue consistently to grow while the developing nations' economieswill eventually collapse in the end. The foregoing buttresses the fact that developed countries since 1947 subsidized their own industries through great compromises to keep their prices of domestic produce low. The ploy is to shut out competition between the poorer countries and the developed countries. This account amongst many other reasons why this study seeks to investigate the advantages of African membership at WTO17 currently.

\section{Africa'sSub-RegionalTrade Integration.}

Africa as a continent has realised lately through, the non-yielding partnership of her marriageof trade development at the WTO level. The realisation ought to have been taken into consideration since the 1990s when the region had always recorded a trade deficit, heavy debt burden, dependency on foreign ideas of development and placing reliance on imported goods and services rather than place reliance on its home-grown initiates which incorporates its culture of development. Most dynamic African leaders now realise that economic integration is a priceless tool hence creation of regional organizations for economic integration and cooperation has been initiated by some trade blocks of countries in Africa. Part of the argument canvassed for the establishment of most of the regional organizations in Africa and these includes Economic Community of West African States (ECOWAS) is rooted on regional economic and trade integration.

For instance, the establishment of OHADA has unified regional business laws to an extent unheard-of anywhere else in the region. Until recently, most African states suffered from outdated legal systems, some dating from 1807, the time of Napoleon. Since its creation in 1993, OHADA has designed, enforced and applied through the courts a substantial body of uniform commercial laws. ${ }^{18}$ The present dominance of the French language and of civil law within OHADA is expected to change over time as OHADA embraces other African countries. OHADA was conceived in a French- speaking area, African leaders have quickly come to understood that this priceless tool of economic integration should be extended to other countries in Africa. ${ }^{19}$ Guinea-Bissau and Equatorial Guinea soon became members, and now, with the advent of the New Partnership for African Development, (NEPAD), OHADA's extension to English-speaking African countries is inevitable. Apart from OHADA's geographic expansion, there are still important challenges ahead. These include the financing of OHADA institutions. The life wire of any strong organization is funding especially when the organization is institutionally based comprising of many heads of government. Most member countries have always view OHADA as an important opportunity for integrating African economies into the global economy. It is also believed that it creates an enabling environment for regional member countries to increase intra-African trade; which would serve as an example of economies of scale in making law reforms. The recent OHADA achievements show justification for the establishment of the organization. Since its creation, seven provisions of its laws are now directly applicable in all sixteen OHADA countries.20 Other areas of achievement in the pipeline are the preparation of the labour law, transport law, contracts law, competition law and law on cooperatives. The Common Court of Justice ad Arbitration is located in Abidjan, Côte d'Ivoire. It should be noted that between November 2001, and 15 October 2002when the Court started its activities, the Court had received 87 cases from ten countries, of which 32 has received judgment while 55 are pending. ${ }^{21}$ This is very encouraging considering transport and communications difficulties in the region.Positive analysis of law is concerned with how agents behave in response to legal rules and how legal rules are shaped to either accommodates such behaviour or proscribed the behavior while prescriptive analysis concerns what rules should be adopted to advance specified objectives. ${ }^{2}$ Bearing in mind the above, are a few legal instruments which have assigned themselves more ambitious objectives than the Organization for the Harmonization of Business Law in Africa. ${ }^{23}$

\footnotetext{
${ }^{16}$ Kubzansky, M.,Chidzero, B.,Cooper A., (2011) "Promise and Progress: Market-based solutions to poverty in Africa."Available on file://C:/Users/ECS/Downloads/Documents/Africa-\%20PromiseAndProgress-MIM_2.pdf.Accessedon 24/7/2017.

17 The study does not concludes nor bases its research on the failures of the current regional arrangements within Africa but rather, it sought to propose a legal framework for the establishment of an African owned trade organization which is made- in- Africa-for- Africa trade.

${ }^{18}$ Enonchong, N., "The Harmonization of Business Law in Africa: Is Article 42 of the OHADA Treaty a Problem?" (2007), 51, 1 pp. 95 - 116, Journal of African Law,. See also Article 2 of the Treaty.

${ }^{19}$ The statement was credited to Judge KëbaMbaye, the former president of the international Court of Justice at one of the sessions of OHADA.

${ }^{20}$ The provisions include general commercial law; corporate law; laws concerning guarantees and collaterals; debt recovery andenforcement law; bankruptcy law; arbitration law and accounting law.

${ }^{21}$ During the same period, the Court received five requests for arbitration, for which two awards have been granted and three are still pending. On it is Regional Training Centre for Legal Officers in (Porto Novo, Benin Republic, in 2002, the Centre organized some 40 regional and national seminars on OHADA law for judges, notaries, lawyers, court experts, registrars, bailiffs and magistrates

${ }^{22}$ Christin, J. C. Sunstein, R., Thaler, R., "A Behavioral Approach to Law and Economics" (1998) Vol. 50, No. pp. 1471 -1550, Stanford Law Review,. Available at .jstor.org.Accessed: 11-02-2017.

${ }^{23}$ Beauchard,R., Mahutodji,J.,Kodo V., “Can OHADA Increase Legal Certainty in Africa?” (2011), . p. 5, Justice\& Development, working Paper.
} 


\section{A Case for Establishment of African Economic Trade Organization (AETO)}

Commercial laws in Africa are out-pacing commercial practices in most countries by a very wide margin. It was argued by Igbanugo and Adiyia ${ }^{24}$ that most regions of Sub-Saharan Africa are in connection with the development of harmonized commodity and transactional laws. These laws aimed to foster regional and international trade. In recent time, most Sub-Saharan African nations suffered from outdated legal systems. One of the ways to come out of these dead laws is through economic groupings within the continent.25 The member states are for the purposes of advancing to integrate trade protocols with certainty of efficient legal architecture.The Common Market for Eastern and Southern Africa (COMESA) has twenty-five-member countries. It needs be mentioned that most countries in the Southern African Development Community (SADC) region are currently eying similar initiatives. However, the foregoing notwithstanding, Africa is changing for better as there is a willing heart and the zeal for economic freedom within the region. That is, the readiness to solve some of the existing problems in the African Union; reaching a compromise and concession by member countries to give room for the formation of a strong economic trade organization for Africa.

Aside the above, the problem of diversity of laws remains a major problem in the circle of regional integration. Indirectly put, diversity of African ought to make the region strong and not serve as an obstacle to African economic development. It is being argued that this aspect has not been the subject of any intensive consideration or given attention by African states. ${ }^{26}$ The writer notes the above argument may not be the present situation as some commercial regional laws agreement.Notably, there is a wide disparity between matters of private essential law to a widespread change in the traditionally subordinate role which law plays in the contract of private business. ${ }^{27}$ Notwithstanding the foregoing, some of these laws met certain passionate reception by African policymakers; the reality is that it has not occasioned the desired change in individual attitudes and principles essential to a widespread change in the habitually subordinate role of laws to power play at WTO. The resultant effect is that it brought into being a significant gap between written commercial laws and commercial behaviors in most developing countries.

Trade practices and sales of products unlike any other human endeavour, are fundamentally important to countries all over the world. There is need to have a focus in commercial agreements which binds contracting parties and it should not be left in one party's domain to dictate or decide the fate of the other party. Noteworthy also, is fact that rules, when created and are uniform in nature are easy to manage and apply but it needs not be created in uniform structure and this is often the problems in commercial agreements in low-income countries of Africa. It is prominent in Africa that a primary product of low level processing accounts for the bulk of national production exports. ${ }^{28}$ Development demands could easily pass for a lost ambition in theexpedition of African region at WTO if not strategically handled.

The present low level of trade in Africa has taken a different dimension than the earlier economic growth expectation envisaged by the continent. The introduction of part IV into GATT in 1965 on the recommendation of the GATT committee on Trade and Agreement was such that developing countries were somewhat absolved from reciprocal commitment under part IV of GATT. They were also marginalised from the future key decision-making in the system. ${ }^{29}$ The effect is that Africa must search inwards for its development needs in terms of how it can boost its economy. The structure of WTO, the GATT rules and its own structure notwithstanding, the aptness or otherwise of such structure has not given any country in Africa the needed opportunity for trade growth because of the barriers of tariffs as all members are bound by GATT rules. There is a steady growing realisation among developing countries of the need to for trade expansion but it is increasing danger of being jeopardised. ${ }^{30}$

Questioning how Africa can achieve trade growth which ought to lead to economic development with its membership in WTO especially, with the highly technical GATT rules as annexed to WTO, the way forward is a home-grown economic strategy. The technicalities of GATT rules explain why Arthur Lewis ${ }^{31}$ analysed the consequences of a slowdown of the engine of growth in developing countries (LDCs) and proposed a strategy to revive it. The engine, according to Lewis, is trade, which in the past was fueled by industrial growth in developed countries. He attributed the slow down to a secular decline in the

\footnotetext{
${ }^{24}$ Igbanugo, H. A.,Adiyia, F., “The Harmonization of Business Law In Africa: Possibility or Fantasy?” (2009), The African Counsel, Vol.1, Issue 2.

${ }^{25} \mathrm{Id}$.

${ }^{26}$ Gbenga, B., "Transnational Law, Unification and Harmonization of International Commercial Law in Africa." (1994), Vol. 38, No. 2 pp. 125-143, Journal of African Law, , School of Oriental and African Studies. Available online at www.jstor.org.Accessed on 11/02/2017. See also the argument of H. W. Arndt on Asia.

${ }^{27}$ McConnaughay, P., "Rethinking The Role Of Law And Contracts In East- West Commercial Relations" (2000) Law and Economics Working Papers Series. University of Illinois, College of Law.

${ }^{28}$ The World Bank report of Committee on Trade and Development. Participation of developing countries in World Trade: Overview of major trends and underlying factors (1996), WT/COMTD/W/15.

${ }^{29}$ Mike Campbell (Pvt) Ltd et al. v. Republic of Zimbabwe,Supra not 78 at page 27. See also Trade and Development. Part IV, GATT, 1947 in the GATT Analytical Index. Available Online at wto.org/English_res_e/bookshp_e/gatt_ai_e.htm. Accessed on 29/2/ 2017.

${ }^{30}$ Arndt, H. W., "GATT and the Developing World: Agenda for a New Trade Round." Weltwirtschaftliches Archive, Bd. 123, H. 4(1987), PP. 705718, Springer,jstor.org.Accessed on 23/ 5/2016.

${ }^{31}$ Riedel, J., "Trade as the Engine of Growth in Developing Countries Revisited" (1984) Vol. 94, No. 373, pp. 56-73, The Economic Journal, Wiley for Royal Economic Society. AvailableOnline on www.jstor.org. Accessed on 18/11/2016.
} 
state of economic growth in developed countries since the 1970s. In order to further buttress the disagreement, Africa may not be technically sound in production of sophisticated industrial product such as machineries but it has raw matters which are used in Europe but sales which should earn Africa some good income are clogged with high tariffs.

The only way to keep the engine of LDCs' trade rolling at a fast speed is for the developing countries to turn to alternative sources of fuel..$^{32}$ The strategy to light up the engine of growth is to have a strong single trade institution. The proposed alternative source of fuel by this study is establishment of AETO which is being advocated.33 For instance, the idea of 'differential and more favourable treatment' for developing countries prescribed in GATT 1994 was a logical consequence of an in-ward looking policies ${ }^{34}$ which will never favour Africa.

Inherent in GATT's commercialization was built on the foundation that trade liberalization is less costly 35 is suggestive of the fact that poor countries ought not to pay so much for it on the principle of differential treatment. That expectation never took place. In fact, the principle has been criticized as treating unequal, equally, that is, developing country with advance countries which are not equal in terms of industrialization and technology are put on equal pedestals. The developing countries of Africa knew that unless they are given a preferential and differential treatment, their trade progress at WTO will be in deficit due to the existing rules of GATT in since 1948. This was before most African countries had their independence. It was in 1979 that contracting parties agreed that the principle of differential and more favourable treatment contained in Part IV of GATT rules and other relevant provisions of the General Agreement be invoked when developing countries pressed further to be treated differently.

Wolf 36 argued that developed countries did not expect reciprocity of commitments made by them in negotiations to reduce or remove tariffs by the developing countries but the outcome of the Uruguay round of negotiations shows otherwise.This study argues that by reason of continental differences, technological advancement and certain technical manifestation at the rounds of negotiation, GATT is unfavorable to Africa. The principle of differential treatment is a charade, its idea was a noble cause but its output was ill-fated.The current agitation of developing countries for reduction of tariff is not out of place because GATT rules had long been in existence without consideration by the founders for other LCDs which economic growth are also important to the global community. Another area of concern in WTO is the deceit of how a member state acquires the status of a developing" or "the least developed" 37 country.Traditionally, while WTO have been entitled to self-designate as "developing", acceding members most of the times have been denied the benefits associated with the status in accession during negotiations. It was observed in the course of this study that acceding members at WTO are obliged to join plurilateral agreements in which existing members have option to be either members and WTO agreement have to be implemented without transition periods. Most members affected in joining the plurilateral agreements are mostly developing countries of Africa. It has been argued by writers that the continuous imbalance amount to another lost opportunity to tackle the tradedeveloping relationship between the developed and developing countries ${ }^{38}$. The procedure of implanting the rules of GATT to accommodate the practice in Africa which are dependent countries is difficult.

Roland ${ }^{39}$ argues that many provisions affording "special and differential treatment" (SDT) to developing countries could be interpreted in a way that would make them more operational than they are currently seen to be. The problem lies with the fact that most of the developed countries do not bother about what happens to developing countries' trade as long as they are able to source their raw materials from LDCs. This is notwithstanding if it means keeping the developing country trade as low and as unprofitable as they could be. This is why it is so difficult to give legal effect to the interpretations of the rules of GATT rather than political interpretations where it concerns African trade negotiation.

\footnotetext{
${ }^{32}$ Op. Cit.

${ }^{33}$ This study argues that at the present dispensation, the only viable alternative fuel is to the demobilisation of dependency on imported goods from developed countries, especially those goods that can be produced in developing countries. Africa needs to start with the very little wealth creation at regional level for its trade growth before the craze for international trade. This will help its industry to grow at its developing rate.

${ }^{34}$ It was argued by Oduwole, J. in her paper titled "WTO Special and Differential Treatment: Africa's Golden Fleece or Trojan Horse?" that the effectiveness of Special and Differential Treatment for developing countries as a tool for their development over, the years has been limited. This is because many products where were of significant to developing countries were exempted from the list and the preferences were granted by developed nations on a voluntarily (and selective) basis. This can be withdrawn at any time which makes it to be economically' and politically limiting for African countries and thus, not suitable for the region.

${ }^{35}$ Wolf, M., 'Differential and More Favorable Treatment of Developing Countries and the International Trading System (1987), Vol. 1, No. 4, pp. 647-668, The World Bank Economic Review, Symposium, Oxford University Press.

${ }^{36}$ That developed contracting party shall not seek, neither shall less developed contracting parties required to make, concessions inconsistent with the developed countries' development, in terms of financial and trade needs. That Less-developed contracting parties would ordinarily would not expect that their capacity to make contributions or negotiated concession or take other mutually agreed action under the provisions and procedures of the General Agreement (GA) would then improve with the gradual development of their economies and improvement in their trade situation and from there they would accordingly expect to participate more fully in the framework of rights and obligations under the GA. That Special attention shall be given to the particular salutation and problems of Lease developed countries and to the need to encourage positive measures to facilitate expansion of their trading opportunities

${ }^{37}$ Rolland, S. E., "Development at the World Trade Organization" (2012) Vol. 4: 451, Trade, Law and Development., Oxford Univ. Pres.

${ }^{38} \mathrm{Id}$.

${ }^{39} \mathrm{Id}$.
} 
Noting from the historical antecedent of WTO, all decisions are made by consensus, developing nations seem unable to foot the political cost of breaking the consensus that had existed for decades. As a result of this, developing countries of Africa are put at a more disadvantageous position all the time during rounds of negotiation. This writer suggests that the continuation of membership of African countries at WTO is a liability rather than the attainment of economic freedom, especially on trade level. The study also notes that Africa has her own peculiar economic problems ranging from corruption, war, lack of focus and misplaced priorities of development agenda.However, with all these, the rule of preferential and differential treatment sought for by Africa hasthe lyrics tailored towards boosting of African trade it has become a song with discordant tunes.The failure of equal representation of Africa in WTO, taking into consideration that as members, all decisions reached by consensus are binding on all member states whether favourable or unfavorable is a serious misnomer since the rules of GATT are sacrosanct. Bown ${ }^{40}$ argued from a background that that there is empirical evidence that there is equal treatment in multilateral trade agreements like the GATT and WTO and preferential trade agreements is the multilateral agreements' inclusion of a most-favoured-nation (MFN). Again, the extent to which members actually follow the MFN principle as stated by the rules is questionable. For instance, the issue of preferential trade agreements (PTAs) by its nature allows countries to discriminate by offering better terms of market access referred to as 'free trade' to member country. This means that a member country chooses which member country it likes to offer differential treatment and countries it would like to discriminate against in terms of trade.

\subsection{AETO as A Made- In-Africa for African Trade Organization}

Africa as a continent need rethink her present position at the world Trade Organization (WTO) in order to decide whether is it is more beneficial to continue to maintain her membership orshe is better off without her membership at WTO. Her membership at the trade organization has not improved her trade because the market share is less than 10 percent. Trade became the option since diseases ${ }^{41}$ associated with foreign aiddependence has made ODA as unsafe haven for the continent.The problemof aid dependency started from the colonial days and is dated. Another associated problem is the mono-economic planning by some countries in Africa, that is, over dependency on oil! The fall in prices of crude oil is a further testimony of the problems of economic development in the region. The way forward is the realisation that there is a need to develop a holistic African market institution with a strong legal architectural backing as an initiative to encourage export market. Africa can actually thrive in trade development within African because of the massive population. Africa must take its destiny by its hands. The trend of things so far witnessed at the WTO has not changed Africa's economies to a fortune through trade and this will not change in the near future.42

It is rather amazing that Africa finds herself juxtaposed, facing the unparalleled economic crisis with the West in trade bargains under the MFN rule of equality treatment and yet such treatments are not given recognition by the GATT rule in agricultural produce from Africa. Persistent failure of African actors to reach an accord on a legally enforceable and binding rule $^{43}$ for one trade institution is a malaise of while Africa's trade suffers depression at the global market. The quantitative restriction has created a potential and adverse impact on and a hindrance to economic growth in the region but that has gradually changing. It is envisaged that in the next ten or fifteen years, Africa will be faced with no better choice than to determine its fate on whether to advance its region towards economic prosperity or slips backward towards economic disintegration. ${ }^{44}$ Africa may choose to influence her growth by taking a policy standpoint or fall with the weather as it has been for lack of cohesive policy that matches its future economic growth. Most of the industries in Africa presently suffer from headache of lack of electricity, industrial machine spare parts, mismanagement and corruption. The above factors led most industries to gradually fold up in many parts of the continent. Other factors include high tariffs on her products in countries like Nigeria. ${ }^{45}$ Also, there is ineffective pricing policy ${ }^{46}$ and the high cost of importation which had existed for too long due to exchange rates. The result is the decline in exports which will never allow a balance of payment due to unsubsidized imported machineries necessary for industrialization in Africa. With the above argument in mind, Africa must the opportunity offered by this study to establish her own made-in-Africa-African trade organization. The key to sustainable development in Africa is

\footnotetext{
${ }^{40}$ Bown, C. P., Trade Policy under the GATT/WTO: Empirical Evidence of the Equal Treatment Rule, (2004), Vol. 37, No. 3. pp. 678-720, Canadian Journal of Economics / Revue canadienned'Economique,.

${ }^{41}$ N. Birdsall "Seven Deadly Sins: Reflections on Donor Failings."(2005) Center for Global Development.

${ }^{42}$ The establishment of the World Trade Organization (WTO) popularly known as the Marrakesh Agreement is an international convention within the meaning of Article 3 1(1) (a) of WTO agreement. There are other series of annexed agreements and legal instruments dealing with trade in goods and service as well as intellectual property rights. By the provision of Article 38 (1) (a), all members are expected to submits to Resolution of Dispute Understanding (DSU) upon accession of membership. In other words, Article 38 (1) (a) which is the rules of DSU is automatically recognised by the contesting states 99 who must submit to the dispute settlement procedures.

${ }^{43}$ Oke, Y., "Sub-Saharan Africa and Climate Change: Revisiting the Multiple Stresses Factor and Adaptation Strategies of ECOWAS and SADC Zones.” (2013) Vol. 3 (1) SADC Law Journal.

Browne, ${ }^{44}$ R. S., “Africa's Economic Future: Development or Disintegration?” (1984) Vol. 1, No. 4. pp. 793-812, World Policy Journal, Duke University Press. www.jstor.org. Accessed on the November 18, 2015

${ }^{45}$ 1n case of Nigeria, Michelin Tyre Industries relocated from Nigeria to Ghana some years back mainly due to cost of running power supply for production of tyre. There is no electricity or at best supplied haphazardly in Nigeria and the problem has continued unabated till date. ${ }^{46} I d$.
} 
fostering of interaction and exchange of information and networking within the continent especially, Sub-Saharan Africa with a strong common anti-corruption law for all of Africa. As Africans, we have always understood Africa's close historical ties, its rich contributions to our own cultural and artistic heritage. At the same time, some works in Africa brought to her, more than too many Americans, the impact of the deepening economic, social and political crisis that has seemingly engulfed all aspects of African life.47 We all know the economic features of that crisis: worsening terms of trade, ${ }^{48}$ growing national and international debt, devaluation and austerity programs which have undermined the real incomes of most Africancountries. ${ }^{49}$

While it is not in doubt that colonization has its own problems and may have contributed to the economic subjugation of Africa, this study argues that this is only a part of it and not the whole problem. . $^{\circ}$ For example, suppose Africa had colonised Europe, will there be any difference in terms of economic growth than what the region is presently? Africa witnessed an early development of a pattern of Europe which seeing Africa as a source of raw materials and only a consumer of goods. ${ }^{51}$ The result of such uneven trade is evident of lack of industrialization in the continent. The idea that centuries of African slavery and colonisation bedeviled the economic development 52 in Africa is now a lame duck excuses, especially with the presence of incontrovertible economic opportunities and the cooperative arrangement in form of sub-regional economic integration within the region. The lack of trade opportunities for self realisation in Africa resulted in heavy debt, deaths, human suffering, unintended emigration, brain drain of our people, deprivation, loss of human dignity and hope. ${ }^{53}$ What Africa is currently lacking is a strong trade institution with very strong economic laws with legal teeth of punitive measures.

This is study finds that it is curious that GATT failed to enforce itsrule of anti- dumping where it concerns goods produced in Europe and America which are daily dumped in developing countries. ${ }^{54} \mathrm{Also}$, the developing countries are reluctant to push for enforcement of the rule because they are deep into import- dependency for home consumption including basic needs. This

must change. For instance, most unserviceable auto spear parts are pushed to developing countries. Most local markets of developing countries like Nigeria, Ghana, Benin Republic and a host of others are flooded with used clothes, used cars, and used shoes, toys and other article of commerce. At some point, the United States, Canada and the European Community have all pressed Japan under the anti- dumping rules on autos and have also limit textile trade from developing countries like Africa in the Multifiber Agreement (MFA), Japan threatened to impose anti-dumping duties on U.S petrochemical imports 55 the West and other European countries soft pedal on carrying out their threat. Africa cannot boast of issuing such threat because of its poor economic standing. This informed why nothing is being said with respect to dumping of used goods in most African markets. It may be argued that the choice is that of Africa but how can the region make a choice when it has nothing on ground from which to make such choice in the first place due to its trade restrictions at the international trade market?

It is further argued that while there is nothing wrong with trade liberalization of WTO, the perception of quid pro quo trade concession is meaningless. ${ }^{56}$ Trade liberalization is good but its commercial treaties are difficult bargains. The effect is that international forces are working and shaping the relationships and hierarchies between state economic interest and regions of the world. ${ }^{57 B e t w e e n ~ t h e ~ 1950 s ~ a n d ~ 1960 s, ~ d e v e l o p m e n t ~ w a s ~ f i g u r e d ~ s i m p l y ~ a s ~ e c o n o m i c ~ i n c r e a s e ~ a s ~ q u a n t i f i e d ~ b y ~}$ gross national product and per capita income in individual developing countries. ${ }^{58 T h e}$ modern concern of economic growth goes beyond the equitable distribution of economic resources increase and the needs of poor countries. Economic growth nowadays includes the pressure to be relevant in the international economics which is very essential to the welfare of nations.

\footnotetext{
${ }^{47}$ A. Sideman," Towards a New Vision of Sustainable Development in Africa: Presidential Address in1990 Annual Meeting of the African Studies Association." (1992) African Studies Review, Vol. 35. No. 1, pp. 1-15. Cambridge University Press. Available Online at www.jstor.org.Accessed on the $30-4-2017$.

${ }^{48}$ Ibid.

${ }^{49}$ Ibid.

${ }^{50}$ Africa suffered a lot from lost hope. If anything, to go by dimensions of independence is self-rule and self-development, the region may be described to have slid downward on both dimensions over the past thirty-five years. This is not only in its governance, law and economic development but also in the procedures it undertook ion handling such matters.

${ }^{51}$ Dwayne, J., "The Impact of Colonialism on African Economic Development" (1996), Settles University of Tennessee - Knoxville. Trace: Tennessee Research and Creative Exchange.

${ }^{53}$ UNCTAD, "Foreign Direct Investment in Africa", (1999) New York, Available at www.unctad.org/en/doc /poiteiitem1501.pdf. Accessed 7/4/ 2017.

${ }^{54}$ There can never be equality in trade bargain emanated from trade agreements made years back without the contemplation of the African economies. Africans complain about this unequal treatment while people of dominant culture sigh, they slouch, they giggled and they say, slavery is over. If slavery over of human beings is over, economic slavery has taken its place and this is where the world stands today. This is a reality.

${ }^{55}$ Schott, J. J, "Can World Trade Be Governed?" (1982) Vol. 25, No.1. pp. 43-49, Challenge, Taylor \& Francis, Ltd.www.jstor.org.Accessed on the $21 / 11 / 2016$.

${ }^{56}$ Accominott, O., M. Flandreau, '-Bilateral Treaties and the Most-Favored-Nation Clause: The Myth of Trade Liberalization in the Nineteenth Century" (2008) World Politics, Vol. 60, No. 2. PP. 147-188. Cambridge University Press.Available Online at www.jstor.org. Accessed on the 2211- 2016

${ }^{57}$ Telo, M., "Introduction: Globalisation, New Regionalism and the Role of the European Union" referred to in M. Telo (ed.), European Union and New Regionalism: Regional Actors and Global Governance in a Post-Hegemonic Era, (2001), Ashgate at p. 15.

${ }^{58}$ Samuelson, P., "A less developed country is simply one with real per capita income that is low relative to the present- day per capita income of such nations as Canada, the United States, Great Britain, and Western Europe. (1973) 765 9th ed. Economics.
} 
Africa stands to gain so much from the formation of AETO being advocated in this study. The advantages can be seen from other regional organizations already existing in the region such as COMESA, SADC and ECOWAS previously discussed in this study. The difference between the above-namedorganizations and the one being advocated in this study is that while AETO is for all Africa, the existing sub-regional organizations are segmentalised, in piecemeal and only covering specific regions in Africa. While these organizations are prospering African economy through regional integration, they do not represent a single trade Organization for Africa.

\section{Findings.}

- $\quad$ The organizations are not all embracing because they are conglomerates of sub-regional organizations. The pooling of resources together by African countries as a force to negotiate at the WTO rounds is a key to prosperity of African economy. This explains why AETO is non- negotiable.

- $\quad$ At the moment, it is taken that both policymakers in Africa and scholars have finally understood that development is not purely an economic phenomenon but has also social, political, and institutional dimensions, causes and objectives 59 as its components. Thus, in recent time, the economies of most African countries are shaped by grand politics, controlled by government policies by setting their priorities.

- It was not perceived in the past that government was also to be a primary economic actor in many sectors of the economy. Most government corporations and public enterprises were built to carry out certain economic utilities which the private sector cannot provide. These ranges from manufacturing to transportation, public utilities such as railways and electricity in some countries in Africa. The provision of these utilities is for public benefits. The step became a child of necessity because the private sector was too small in most developing countries and up till today, adequate financial resources and technical expertise are still lacking. ${ }^{60}$ William Easterly buttresses the fact that foreign aid today perpetrates a cruel hoax on those who wishes the world's poor well. Even at that, the doubling of foreign aid to Africa promised at the 0-8 summit by the United Nations and World Bank plans to cut world poverty in half of 2005 never worked out. 61

- In order to determine the economic future of Africa, it would depend on the steps takenby the policymakers in Africa to advance its prosperity in the long run. However, if no concrete plan is embarked upon, the region will definitely slip backward toward economic disintegration.

- $\quad$ Those who argue that the role United States plays in Africa will mark the success or failure of its economy should however note that the US, even though economically very strong, is also interested in remaining on top of every other nation's economy. Bearing the above explanation in mind, it may choose not to play any tangential role which ought to aid the poor countries in terms of technology, industrialization and human development.

- $\quad$ The lull in the economy of Africa is not entirely based on globalization. The decline in exports has produced a shortage of foreign exchange..$^{62}$ If there is anything Africa badly need now is institutional reforms that permeate all politics of the belly for the promotion of economic development.

- $\quad$ The time is now for Africa to narrow her economic needs to include exclusive focus on sustaining rural infrastructure, participation in common-pool resource situations ${ }^{63}$ for the purposes of situating itself in global market. Such plan should embrace broader spectrum of positive incentives to cooperation and the levels of policymaking and implementing institutions that it considers essential to its economic development. Africa must avoid programmes of shared common feature which costs are typically and heavily front-loaded and the benefits deferred. ${ }^{4}$

- $\quad$ Debt service currently absorbs more than 40 per cent of export earnings in Africa. The question is what should Africa to do in order to bring sanity to her economy especially in the area of trade, law and development? Apart from certain natural causes which are beyond human control, human causes account majorly for most of the problems of the economic lull in Africa.

- It is only Africa and not the West or Europe that will end the recession in the region. Export of home produce can only be expanded when Africa gets its economic rhythm right by starting from its own trade organization. The

\footnotetext{
${ }^{59}$ J. W..Salacuse, "From Developing Countries to Emerging Markets: A Changing Role for Law in the Third World" (1999), Vol. 33, No. 4, pp. 875890, The International Lawyer,. American Bar Association, www.jstor.org.Accessed: 12/01/2017.

${ }^{60}$ Supra, note 104 at page 35 .

${ }^{61}$ Easterly, W., "The Handouts That Feed Poverty" (2006).|Available Online at www.worldhunger.org/artic1es/06/editoria1s/1atimes.htm. Accessed on $28-2-2017$.

${ }^{62}$ The balance of payments deficit keeps growing, even though imports have been severely soared up which has in turn left many industrial plants idle or operating at a fraction capacity; all because they lack raw materials or spare parts.

${ }^{63}$ Ostrom, E.,et al., (1993) 'Institutional Incentives and Sustainable Development: Infrastructure Policies in Perspective. "Boulder: West view Press, pp. 266, L. A. Picard and M. Garrity, "Policy Reform for Sustainable Development in Africa: The Institutional Imperative” (1994,), Boulder: Lynne Rienner Publishers, Inc.

${ }^{64}$ Aguibou Y., "Prospects for Recovery and Sustainable Development in Africa." (1996) Westport: Greenwood Press, 363. Example of countries with nascent adjustment programmes implementation at the time the book was written are Nigeria, Ghana and Cote d'Ivoire.

${ }^{65} 148$ Streeten," P.,'Basic Needs: Some Unsettled Questions" (1984) World Development Institute Easton University.
} 
successes recorded from some of the sub-regional organizations show that the establishment of AETO can only do more to enhance the opportunities of trade growth for Africa.

- $\quad$ This can be achieved when the region is focused and have something to look forward to in place of the prevalence of its economic stagnation. As shown in my previous paper in other studies, continued aid dependency has failed Africa. This paper posits that the dependence of African continent on WTO trade has failed Africa because there is no empirical evidence of any country in the continent which economic growth resulted from its membership of WTO. Africa is still classified as one of the poorest regions in the entire world because its trade cannot grow through the participation WTO. The biggest hope for the world's poor is the citizens of poor nations themselves. It largely depends on what they are able to think and do starting from regional integration and pooling of their common resources from within to compete at the international market.

\section{Conclusion/ Recommendation.}

This paper has attempted to highlight the constraints of past development and the pursuit of strategies for sustainable development through trade in Africa by proposing a legal framework that seemed workable. Components and strategies which have often been mainly employed or abandoned by policy makers have been recommended for implementation in the light of the new development drive. Africa must work in closer collaboration with other Asian colleagues to conduct research as to the causes of Africa's economic crisis and possible strategies for sustainable development through trade laws and market integration. It must be clarified that although the situations in which Africa finds itself are not sufficiently similar with those of South and North East Asia so as to admit common assumptions, but the continent share similar economic and development goals. This explains why AETO is non-negotiable in the region. For development to take place in Africa there must be the new face of Africa in terms of development laws which must be clothed with legal teeth. Such law must incorporate treaty clauses with certain countries in Europe and both the non-align nations and those islands where the treasury looters hide their countries money.

The conceptions of economic development which does not tally with the priorities of the African needs should be abnegated and jettisoned. Africa should see her region as a major source of raw material for Europe and American economies and therefore take the advantage of having her own trade organization to serve as a pooling of resources to be used at negotiation table during WTO rounds with one voice. Africa should dig within for its economic growth because as a major source of raw materials; it is very relevant and crucial to the world economy. The better way is to have a made in Africa for an African market organization. This is achievable in view of the presence of some sub-regional organization in the region. These organizations serve as a stepping stone for possibilities of Africa taking charge of her affairs and in preparation for the formation of AETO for Africa. The politics of basic needs ${ }^{65}$ dictated by oversea donors for Africa must be exchanged with trade bargain and exchange of technology by African policy-makers.

\section{Bibliography}

i. Accominott, O., Bown, C.P., "Trade Policy under the GATT/WTO: Empirical Evidence of the Equal Treatment Rule, (2004), , Vol. 37, No. 3. pp. 678-720, Canadian Journal of Economics / Revue canadienned'Economique.

ii. Adiyia, A., "The Harmonization of Business Law In Africa: Possibility or Fantasy?" (2009), Vol. 1, Issue 2.The African Counsel.

iii. $\quad$ Aguibou, Y.,'Prospects for Recovery and Sustainable Development in Africa.” (1996) Westport: Greenwood Press, 363. Example of countries with nascent adjustment programmes implementation at the time the book was written are Nigeria, Ghana and Cote d'Ivoire.Arndt, H. W., $\quad$ "GATT and the Developing World: Agenda for a New Trade Round." Weltwirtschaftliches Archive, Bd. 123, H. 4(1987), PP. 705-718, Springer,jstor.org.Accessed on 23/ 5 / 2016.

iv. Barbara, R., $\quad$ "Trade Not Aid: Why Trade Facilitation Is Important For Africa." (2011), Africa trade policy notes ; No. 27. Washington, DC: World Bank. http:// documents.worldbank.org/ curated/ en/ 676621468201835737/ Whytrade-facilitation-is-important-for-Africa.

v. Beauchard, R., Birdsall, N., "Seven Deadly Sins: Reflections on Donor Failings."(2005) Center for Global Development.

vi. $\quad$ Browne R. S., "Africa's Economic Future: Development or Disintegration?" (1984) Vol. 1, No. 4. pp. 793-812, World Policy Journal, Duke University Press. www.jstor.org. Accessed on the 18/ 11/ 2015

vii. Chidzero, A., Cooper (2011) "Promise and Progress: Market-based solutions to poverty in Africa."Available on file:/ / C:/ Users/ ECS/ Downloads/ Documents/ Africa-\%20PromiseAndProgress-MIM 2.pdf.Accessedon 24/ 7/ 2017.

viii. Christin, J., Jacobs, D , "Democratizing global economic governance" (2000) Paper presented at the Conference "Alternatives to Neoliberalism: New rules for global finance', NGO-Coalition, Monterrey.

ix. $\quad$ Daemmrich, A., "Epistemic Contests and Legitimacy of the World Trade Organization: The Brazil - USA Cotton Dispute and Incremental Balancing of Global Interests" (2012) Vol. 4(1) p. 200, Trade, Law \& Development. 
x. Dwayne,J., "The Impact of Colonialism on African Economic Development" (1996), Settles University of Tennessee - Knoxville. Trace: Tennessee Research and Creative Exchange.

xi. Easterly, W.,"The Handouts That Feed Poverty” (2006).|Available Online at www.worldhunger.org/artic1es/ 06/ editoria1s/ 1atimes.htm. Accessed on 28 - 2 - 2017.

xii. Enonchong, N., "The Harmonization of Business Law in Africa: Is Article 42 of the OHADA Treaty a Problem?” (2007), Vol. 51, (1) pp. 95 - 116 Journal of African Law.

xiii. Flandreau, M., "Bilateral Treaties and the Most-Favored-Nation Clause: The Myth of Trade Liberalization in the Nineteenth Century" (2008) World Politics, Vol. 60, No. 2. PP. 147-188. Cambridge University Press. Available Online at www.jstor.org. Accessed on the 22-11- 2016.

xiv. GATT rules:Article XX II \& XXIII*B).

xv. Gbenga, B., "Transnational Law, Unification and Harmonization of International Commercial Law in Africa." (1994), Law, Vol. 38, No. 2 pp. 125-143, Journal of African School of Oriental and African Studies. Available online at www.jstor.org.Accessed on 11-02-2017.

xvi. Hardin, R, "The Morality of Law and Economics" (1992) Law and Philosophy,Vol. 11, No. 4 (1992), pp. 331384.Springer.Available at jstor.org.Accessed: 11/2/ 2017.

xvii. Hoeckman, B., "Operationalising the Concept of Policy Space in the WTO: Beyond Special and Differential Treatment". (2005). In Reforming the World Trading System (Reforming the World Trading System, Chapter 11). Journal of International Economic Law, 8(2), 405-424.

xviii. Igbanugo, H, F. Macedo, S., "The Law of Peoples What Self-Governing Peoples Owe to One Another: Universalism, Diversity, and the Law of Peoples" (2003-2004), Vol. 72, p, 1721, Fordham L. Rev. / . Available online at HeineOnline.Accessed on 12/ 1/ 2017.

xix. Kubzansky, M. B.,

xx. Mahutodji,J., Kodo, V., “Can OHADA Increase Legal Certainty in Africa?” (2011), p. 5, Justice\& Development, working Paper.

xxi. McConnaughay, P.,"Rethinking The Role Of Law And Contracts In East- West Commercial Relations” (2000) Law and Economics Working Papers Series. University of Illinois, College of Law.

xxii. Mike Campbell, "Mike Campbell (Pvt) Ltd et al. v. Republic of Zimbabwe. See also Trade and Development. Part IV, GATT, 1947 in the GATT Analytical Index. Available Online at wto.org/English_res_e/ bookshp_e/ gatt_ai_e.htm. Accessed on 29/ 2/ 2017.

xxiii. Oke, Y., "Sub-Saharan Africa and Climate Change: Revisiting the Multiple Stresses Factor and Adaptation Strategies of ECOWAS and SADC Zones."(2013) 3 (1) SADC Law Journal.

xxiv. $\quad$ Ostrom, E. Schroeder, L. Riedel, J. "Trade as the Engine of Growth in Developing Countries Revisited" (1984) The Economic Journal, Vol. 94, No. 373 (Mar., 1984), pp. 56-73, Wiley for Royal Economic Society.Available Onlineat www.jstor.org. Accessed: 18/11/ 2016.

xxv. Rolland, S. E., "Development at the World Trade Organization” (2012) Vol. 4: P. 451, Trade, Law and Development., Oxford Univ. Pres.

xxvi. Salacuse, J. W., "From Developing Countries to Emerging Markets: A Changing Role for Law in the Third World" (1999), The International Lawyer, Vol. 33, No. 4, pp. 875-890. American Bar Association,

xxvii. Samuelson, P., "A Less Developed Country is Simply One with Real per capita: Canada, the United States, Great Britain, and Western Europe" (1973) 9th ed. Economics 765.

xxviii. Schott.J.J., "Can World Trade Be Governed?" (1982) Vol. 25, No.1. pp. 43-49 Challenge, Taylor \& Francis, Ltd.

xxix. Sideman, A., "Towards a New Vision of Sustainable Development in Africa: Presidential Address in1990 Annual Meeting of the African Studies Association." (1992) Vol. 35. No. 1, pp. 1-15. Studies Review, Cambridge University Press.Available Online at www.jstor.org.Accessed on the 30/ 4/ 2017.www.jstor.org.Accessed on the 21/11/ 2016.

xxx. $\quad$ Snyder, F. G., $\quad$ "Law and Development in the Light of Dependency Theory" (1980) Vol. 14, No. 3, pp. 723-804, Law \& Society Review, Contemporary Issues in Law and Social,. Published by Wiley for Law and Society Association.

xxxi. Stepek, M.J., "The Importance Of Commercial Law In The Legal Architecture Of Post-Conflict "New" States" (2008) Vol. 60, p 487, Me. L.

xxxii. Streeten, P., Basic Needs: Some Unsettled Questions" (1984) World Development Institute Easton University.

xxxiii. Sunstein,C. R., Thaler, R., "A Behavioral Approach to Law and Economics” (1998) Vol. 50, pp. 1471 -1550, Stanford Law Review,. Available at .jstor.org.Accessed: 11/ 02/ 2017.

xxxiv. UNCTAD, "Foreign Direct Investment in Africa", (1999) New York, Available at www.unctad.org/ en/ doc / poiteiitem1501.pdf. Accessed 7/ 4/ 2017.

xxxv. Whalley, J., "Special and Differential Treatment in the Millennium Round" (1999) Centre for the Study of Globalisation and Regionalisation (CSGR), University of Warwick, Coventry CV4 7AL, United-Kingdom. Available online at www.csgr.org.Accessed on the 15/11/ 2016.

xxxvi. Wolf, M., "Differential and More Favorable Treatment of Developing Countries and the International Trading System (1987), Vol. 1, No. 4, PP. 647-668, The World Bank Economic Review, Symposium, pp. Oxford University Press. Available on www.jstor.org.Accessed on 18/11/2016. 
xxxvii. World Bank, "The World Bank Report of Committee on Trade and Development. Participation of developing countries in World Trade: Overview of Major Trends and Underlying Factors (1996), WT/ COMTD/ W/ 15.

xxxviii. Wynne, S., "Institutional Incentives and Sustainable Development: Infrastructure Policies in Perspective" (1993) pp. 266, "Boulder: West view Press, L. A. Picard and M. Garrity, "Policy Reform for Sustainable Development in Africa: The Institutional Imperative" (1994,), Boulder: Lynne Rienner Publishers, Inc.

xxxix. Yeoh, P., "International Trade Agreements and Global Economic Governance” (2016) 37(8), 235-243. Comp. Law. 